\title{
The production and characterization of a new active lipase from Acremonium alcalophilum using a plant bioreactor
}

\author{
Eridan Orlando Pereira ${ }^{1,2}$, Adrian Tsang $^{3}$, Tim A McAllister $^{4}$ and Rima Menassa ${ }^{1,2^{*}}$
}

\begin{abstract}
Background: Microorganisms are the most proficient decomposers in nature, using secreted enzymes in the hydrolysis of lignocellulose. As such, they present the most abundant source for discovery of new enzymes. Acremonium alcalophilum is the only known cellulolytic fungus that thrives in alkaline conditions and can be cultured readily in the laboratory. Its optimal conditions for growth are $30^{\circ} \mathrm{C}$ and $\mathrm{pH} 9.0-9.2$. The genome sequence of Acremonium alcalophilum has revealed a large number of genes encoding biomass-degrading enzymes. Among these enzymes, lipases are interesting because of several industrial applications including biofuels, detergent, food processing and textile industries.

Results: We identified a lipA gene in the genome sequence of Acremonium alcalophilum, encoding a protein with a predicted lipase domain with weak sequence identity to characterized enzymes. Unusually, the predicted lipase displays $\approx 30 \%$ amino acid sequence identity to both feruloyl esterase and lipase of Aspergillus niger. LipA, when transiently produced in Nicotiana benthamiana, accumulated to over $9 \%$ of total soluble protein. Plant-produced recombinant LipA is active towards $p$-nitrophenol esters of various carbon chain lengths with peak activity on medium-chain fatty acid (C8). The enzyme is also highly active on xylose tetra-acetate and oat spelt xylan. These results suggests that LipA is a novel lipolytic enzyme that possesses both lipase and acetylxylan esterase activity. We determined that LipA is a glycoprotein with $\mathrm{pH}$ and temperature optima at 8.0 and $40^{\circ} \mathrm{C}$, respectively.

Conclusion: Besides being the first heterologous expression and characterization of a gene coding for a lipase from A. alcalophilum, this report shows that LipA is very versatile exhibiting both acetylxylan esterase and lipase activities potentially useful for diverse industry sectors, and that tobacco is a suitable bioreactor for producing fungal proteins.
\end{abstract}

Keywords: Lipase, Acetylxylan esterase Acremonium alcalophilum, Nicotiana benthamiana, Heterologous expression

\section{Background}

Acremonium alcalophilum is a rare cellulolytic fungus that thrives in alkaline environments and can be readily cultured in the laboratory. Isolated from composted pig manure, it grows optimally at $30^{\circ} \mathrm{C}$ and a $\mathrm{pH}$ 9.0-9.2 [1]. Recently, the genome of $A$. alcalophilum was sequenced (http://genome.jgi-psf.org/Acral2/Acral2.home.html),

\footnotetext{
* Correspondence: Rima.Menassa@agr.gc.ca

${ }^{1}$ Agriculture and Agri-Food Canada, 1391 Sandford Street, London, ON N5V

4T3, Canada

${ }^{2}$ Department of Biology, The University of Western Ontario, London, ON N6A 5B7, Canada

Full list of author information is available at the end of the article
}

providing a rich genetic resource for the identification of enzymes that potentially function under alkaline conditions.

Lipases (EC 3.1.1.3) are one of the most versatile enzyme classes. They are known to have a number of unique characteristics such as substrate specificity, region-specificity, and chiral selectivity [2]. These enzymes belong to a group defined as carboxylesterases that catalyze the hydrolysis of long and short chain acyl esters $[3,4]$. Due to their versatility, the use of lipases as biocatalysts has enormous potential to reduce energy requirements and environmental problems in diverse industries. One example is in the detergent industry where

\section{Biomed Central}


fat stains are difficult to remove at low temperatures. By adding lipases that are active at lower temperatures in detergent formulations, energy consumption is reduced as well as the wear and tear of textile fibers. As biocatalysts, lipases could also replace synthetic detergents, which can cause environmental problems such as eutrophication [5]. These advantages have been explored by several other industries including the textile, food, pulp and paper, fat and oleochemical, pharmaceutical and more recently biofuel industries [6]. With the myriad of potential applications, new expression technologies are needed to meet the anticipated demand and lower the cost of lipase production.

Although lipases are known to occur in a diversity of organisms, including animals, plants and microbes, the current industrial production of these enzymes relies almost exclusively on microbial-based expression systems. Filamentous fungi such as Aspergillus niger and Trichoderma reesei are the workhorses of industry for the production of extracellular enzymes. However, fungi can hyperglycosylate recombinant proteins resulting in reduced activity [7]. An alternative approach is to use plants as bioreactors, transferring the corresponding genes from microorganisms into plants and producing them at economically acceptable levels [8]. Plants offer several advantages over microbes as an alternative expression system for enzymes. These bioreactors utilize sunlight as source of energy and sequester $\mathrm{CO}_{2}$ during photosynthesis. Furthermore, they can undertake posttranslational modification of enzymes such as glycosylation or formation of disulfide bridges, alterations that are often essential for enzyme stability and sustained activity.

To expand our knowledge of lipases with industrial potential and to develop a new production system, we used heterologous expression in tobacco to produce and characterize a lipase from Acremonium alcalophilum. We analyzed the enzyme's yields, post-translational modification and determined its biochemical characteristics.

\section{Results}

\section{Identification of the Acremonium alcalophilum lipase}

With the recent genome sequencing of the alkaliphilic fungus Acremonium alcalophilum, over 200 genes encoding biomass-degrading enzymes were identified. Analysis in silico of the genome revealed a hypothetical protein (protein ID 1062717 of the A. alcalophilum v2.0 database) exhibiting a lipase_3 domain (IPR002921) and weak sequence identity with biochemically characterized fungal proteins. For example, pairwise amino acid sequence alignment using ClustalW2 (www.ebi.ac.uk) revealed 25\% identity to the triglyceride lipase of Aspergillus niger (Accession no. DQ680030, [9]), 24\% identity to the lipase of Thermomyces lanuginosus (Accession no.
O59952, [10]), and 23\% identity to the characterized $A$. niger feruloyl esterase (Accession no. O42807.1, [11]) (Figure 1). Therefore, this novel enzyme was provisionally designated LipA. However, LipA displays some sequence similarity to uncharacterized enzymes such as 57 and 61\% identity to the putative lipases of Glomerella graminicola M1.001 (Accession no. EFQ29359.1), and Verticillium dahliae VdLs.17 (Accession no. EGY21687.1) respectively, and $40 \%$ identity to the putative feruloyl esterases of Trichophyton equinum CBS 127.97 (Accession no.EGE08976.1) and Arthroderma otae CBS 113480 (Accession no. XP 002843470.1). Taking into consideration the low sequence similarity to two different enzyme activities, and that sequence-based analysis only provides a presumptive compositional and functional blueprint of the gene analyzed, which in some cases may lead to erroneous assignment of substrate specificity [2], we assessed LipA for both lipase and carbohydrate esterase activity.

\section{Molecular analysis of plant-made LipA}

The open-reading frame of the gene encoding LipA is $1128 \mathrm{bp}$ long and encodes a protein of 376 amino acids, with a calculated molecular mass of $41.4 \mathrm{kDa}$. The deduced amino acid sequence contains one putative $N$-glycosylation site, suggesting that glycosylation could be important for enzyme functionality.

To characterize LipA properties, we attempted to over-express the lipA gene in $A$. niger, and in the plant Nicotiana benthamiana. We were unsuccessful in obtaining LipA expression in A. niger (data not shown), but obtained high expression in $N$. benthamiana in transient co-expression of the lipA gene (Figure 2) with the suppressor of posttranscriptional gene silencing p19 [12]. Crude extracts as well as C-myc purified proteins from pooled samples from five different plants were resolved by SDS-PAGE and GelCode ${ }^{\mathrm{Tm}}$ Blue staining and were confirmed by western blot analysis with monoclonal antibodies against the fused $\mathrm{C}$-myc tag. This analysis showed that the plant-produced LipA protein has a molecular mass of about $56 \mathrm{kDa}$ (Figure 3a and b). The observed band was larger than the predicted theoretical molecular weight of $46 \mathrm{kDa}$ as the tags add about $5 \mathrm{kDa}$ to the $41 \mathrm{kDa}$ protein. As LipA has a putative $N$ glycosylation site, a deglycosylation experiment was performed by digesting LipA with $N$-glycosidase $\mathrm{F}$ (PNGase F). This led to a small downshift in the band size (Figure 4). However, even with deglycosylation, the molecular mass (46 kDa) predicted from the cDNA was substantially lower than that determined by SDS-PAGE. Since intrinsic charge can lead to anomalous migration on SDS-PAGE [13], this difference may reflect the acidic nature of LipA protein, which has an estimated pI of 4.9. 


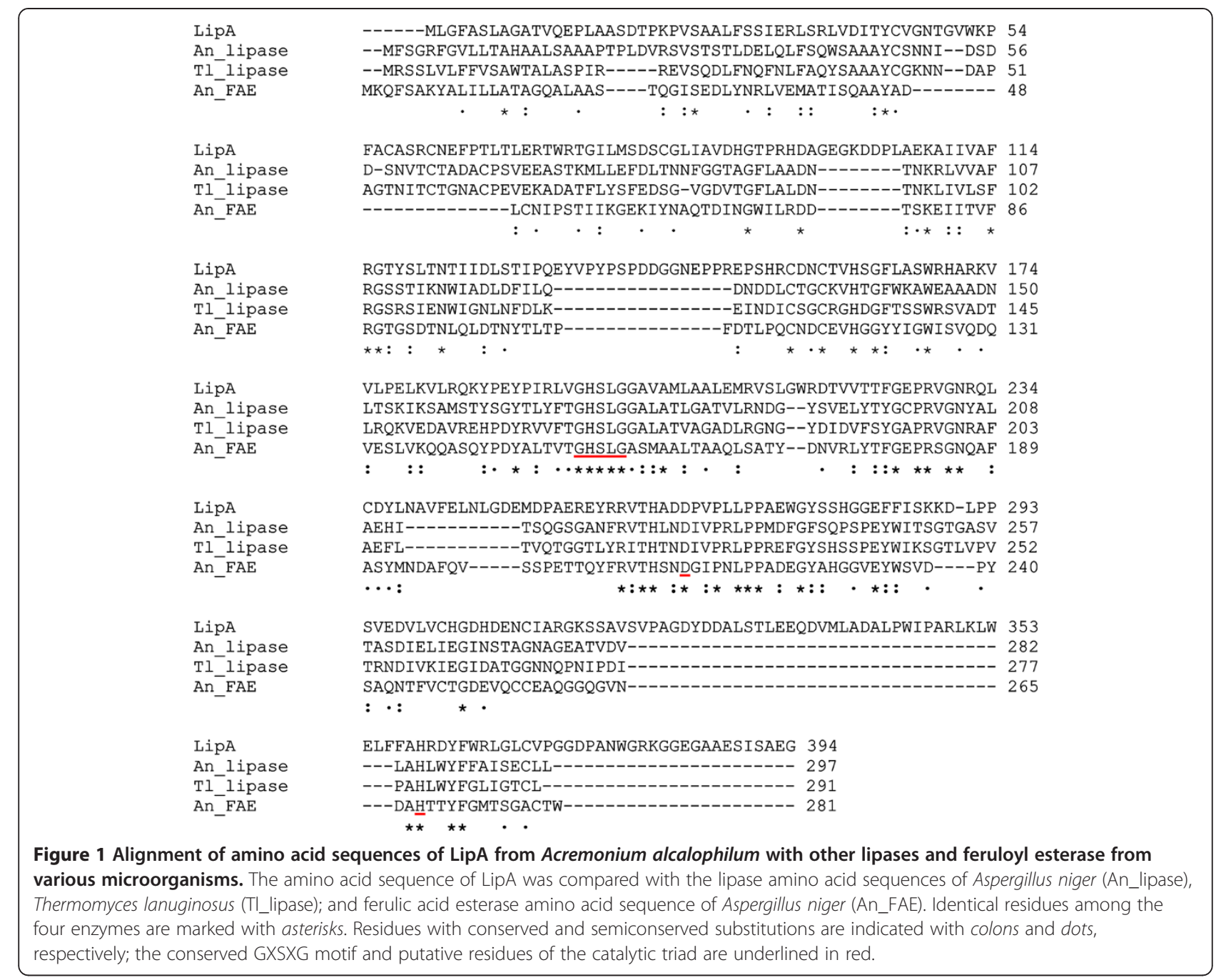

Based on densitometry analysis of western blot results, LipA accumulated to $9.3 \%$ of total soluble protein (TSP) (Figure 3B) which corresponds to approximately $2 \mathrm{~g}$ of enzyme per $\mathrm{Kg}$ of fresh leaf weight. LipA accumulation in our experiments was higher than most in plantaexpressed glycosyl hydrolases described in the literature [14]. Although a few exceptions with higher expression levels have been described [14], to our knowledge, this is the first time an enzyme with the characteristics presented here has been produced in plants at such high levels.

\section{Effects of $\mathrm{pH}$ and temperature on recombinant LipA activity}

As the goal of this study was to identify and characterize alkaliphilic enzymes for potential application in industrial processes, temperature and $\mathrm{pH}$ optima are important characteristics for the efficient usage of this enzyme. Purified plant-produced LipA was used to study the effect of $\mathrm{pH}$ and temperature using $p$-nitrophenyl caprylate as substrate. The optimal $\mathrm{pH}$ of purified LipA under the standard assay conditions was found to be $\mathrm{pH} 8.0$ (Figure 5a). The enzyme showed maximum lipase

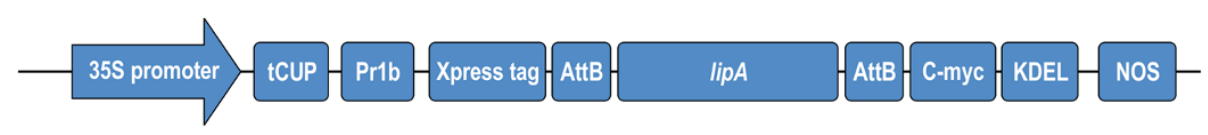

Figure 2 Schematic representation of the lipA expression cassette. 355 promoter, 35 S promoter from Cauliflower Mosaic Virus $35 S$ gene; NOS, nopaline synthase terminator; tCUP, tobacco crypric upstream promoter translation enhancer; Pr1b, tobacco pathogenesis related $1 \mathrm{~b}$ protein secretory signal peptide; Xpress ${ }^{\mathrm{TM}}$, epitope tag (Invitrogen); attB1 and attB2, Gateway ${ }^{\circledR}$ recombination sites; C-myc, detection/purification tag; $\mathrm{KDEL}$, endoplasmic reticulum retrieval tetrapeptide. Schematic not drawn to scale. 


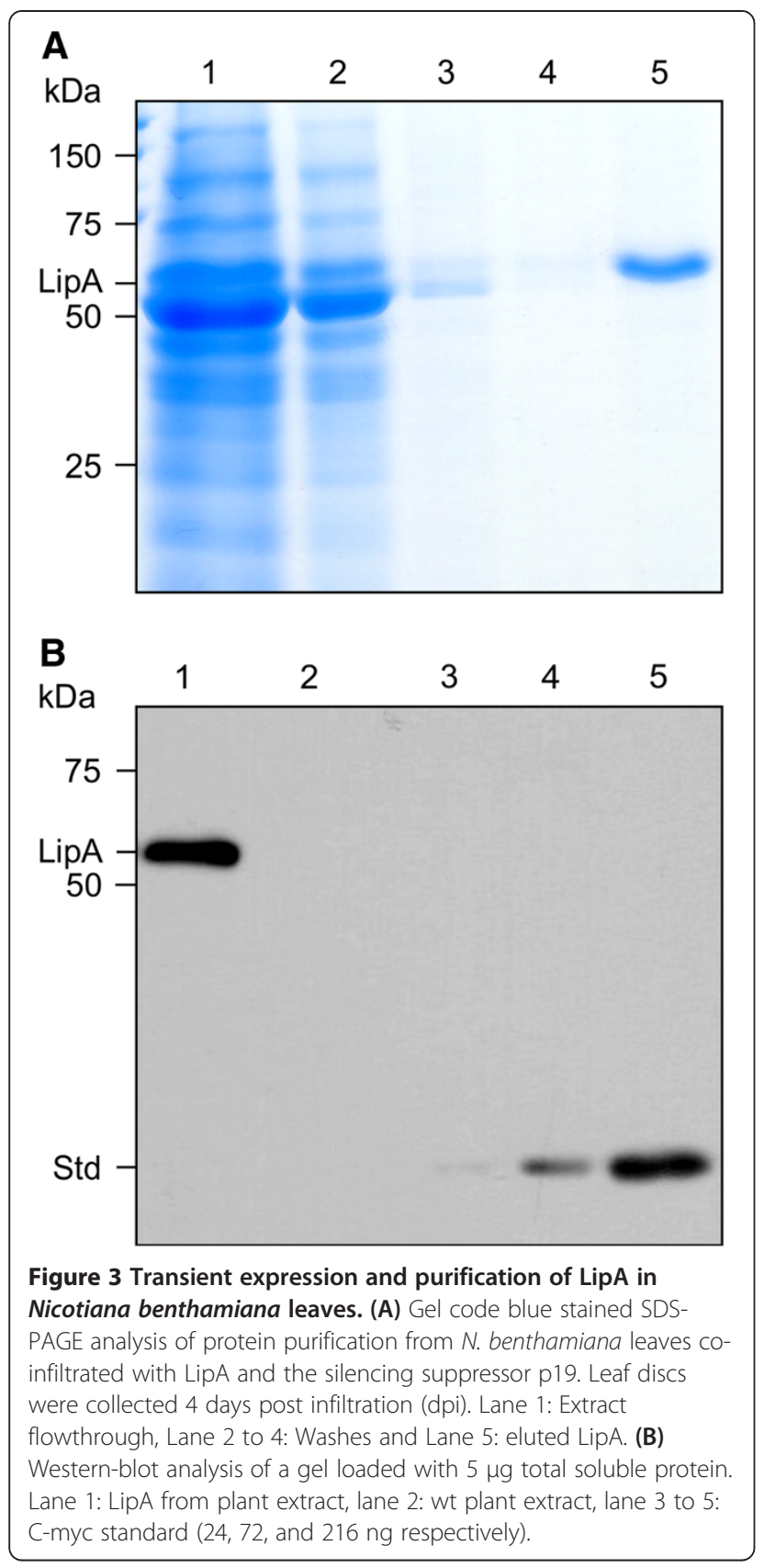

activity at $40^{\circ} \mathrm{C}$ with broad thermostability ranging from $20 \mathrm{C}$ to $50^{\circ} \mathrm{C}$ (Figure $5 \mathrm{~b}$ ).

\section{Substrate specificity of LipA esterase}

As the gene of interest possessed a sequence similar to that of other genes coding for lipases and feruloyl esterases we evaluated the specificity/preference of LipA for a variety of fatty acid and hydroxycinnamate ester substrates. To investigate the substrate specificity of LipA, the hydrolyzing activity of the purified enzyme was determined at its $\mathrm{pH}$ and temperature optima of $\mathrm{pH} 8.0$ and $40^{\circ} \mathrm{C}$, respectively. The substrates analyzed included

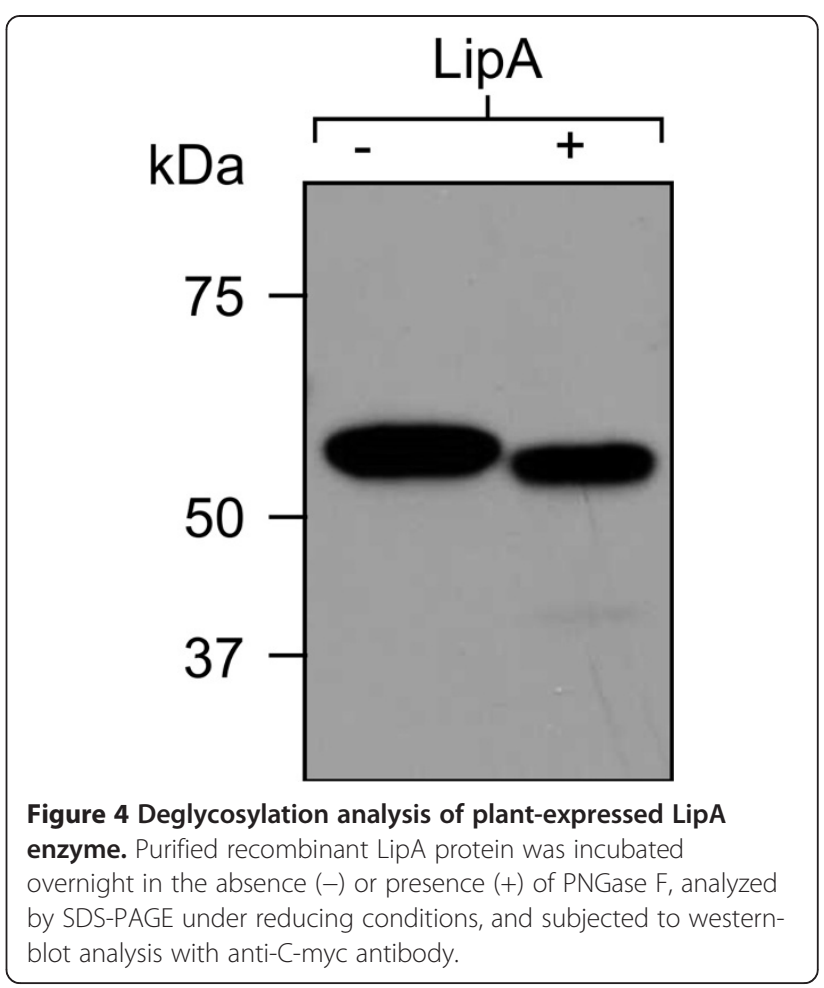

$p \mathrm{NP}$ esters of various carbon chain lengths, methyl cinnamates and the acetylated compounds oat spelt xylan and xylose tetra-acetate. As shown in Figure 6, LipA exhibited low specificity preference towards short chain $p \mathrm{NP}$ ester $\left(\mathrm{C}_{2}\right)$ and intermediate activity towards long-chain $p \mathrm{NP}$ esters $\left(\mathrm{C}_{14}\right.$ and $\left.\mathrm{C}_{16}\right)$. Although lipases are capable of hydrolyzing long chain fatty acid esters, some lipases have maximum activity towards medium or shorter acyl groups. LipA had a clear preference for medium chain fatty acid ester ( $p$ NP caprylate, C8) (Figure 6) demonstrating substrate specificity similar to that obtained with other lipases from microorganisms such as Bacillus stearothermophilus L1 [15] and Aeromonas sp. LPB 4 [16]. The enzyme showed a very broad activity toward $p$ NP esters with the exception of $p \mathrm{NP}$ arabinopyranoside, $p \mathrm{NP}$ arabinofuranoside and $p$ NP xylopyranoside (Table 1), illustrating its specificity towards the hydrolysis of acyl esters but no activity towards aromatic residues. No activity was found towards methyl cinnamate suggesting that this enzyme has no hydroxycinnamoyl esterase properties (Table 1).

The kinetic analysis of LipA was determined in $100 \mathrm{mM}$ phosphate buffer $(\mathrm{pH} 8.0)$ at $40^{\circ} \mathrm{C}$ over a concentration range of 0.1 to $1 \mathrm{mM}$ of $p \mathrm{NP}$ substrates. LipA showed lower affinity towards short fatty acid esters ( $p$ NP acetate, $\mathrm{K}_{\mathrm{m}} 0.15 \mathrm{mM}$ ) and as expected, higher affinity was observed for esters with medium and long carbon chain (Table 2). 

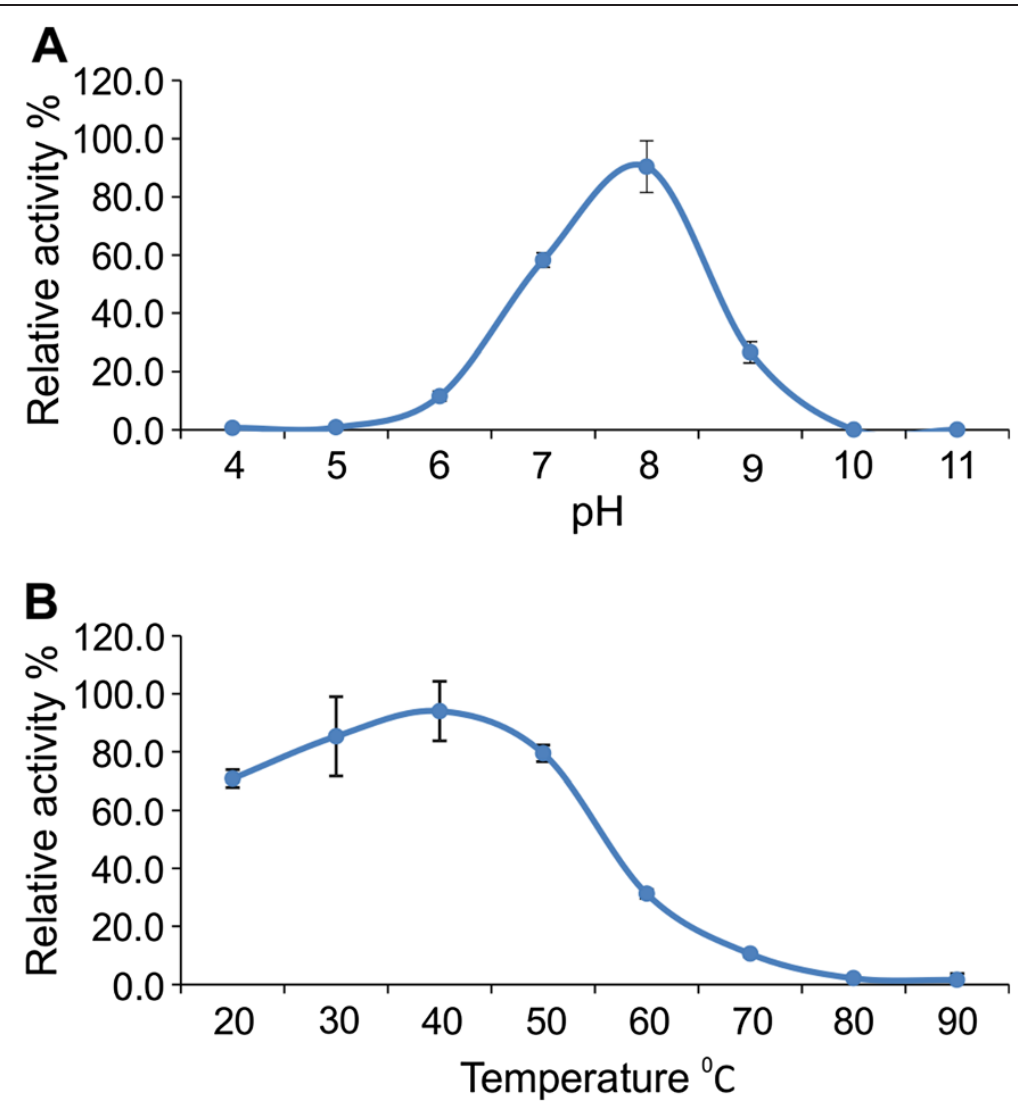

Figure 5 Effect of $\mathbf{p H}$ and temperature on LipA enzyme activity. (A) The influence of $\mathrm{pH}$ on activity was determined using $1 \mathrm{mM}$ pNPcaprylate in $100 \mathrm{mM}$ buffers ( $\mathrm{pH}$ 4.0-5.0 acetate buffer, pH 6.0-9.0 phosphate buffer, $\mathrm{pH}$ 10.0-11.0 carbonate buffer) at $40^{\circ} \mathrm{C}$ for $30 \mathrm{~min}$. (B) The influence of temperature was determined in a range from $20-90^{\circ} \mathrm{C}$ using $1 \mathrm{mM}$ pNP caprylate in $100 \mathrm{mM}$ phosphate buffer pH 7.0 for $30 \mathrm{~min}$. The test was performed in triplicate and the average values were transformed in the relative activity (\%).

Although the results using $p \mathrm{NP}$ substrates indicate that LipA has a higher activity towards medium chain fatty acid esters (Figure 6), LipA demonstrated acetylxylan esterase activity against xylose tetra-acetate (58 U/mg, Table 1) that was similar or higher than the acetylxylan esterase of Bacillus purmilus (37 U/mg)

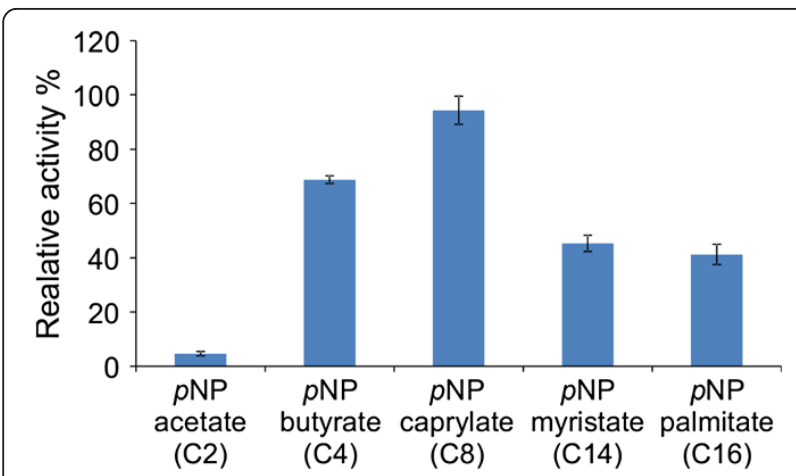

Figure 6 Substrate specificity of the lipase from Acremonium alcalophilum towards $p$-Nitrophenol fatty acid esters with varied acyl chain lengths. Values are means \pm SD $(n=3)$.
[17] and Fibrobacter succinogenes Axe6A (11.4 U/mg) and Axe6B (1.3 U/mg) [18]. LipA also showed similar or higher specific activity against acetylated xylan (14 $\mathrm{U} / \mathrm{mg}$, Table 1) when compared with acetylxylan esterases of bacterial species: S. flavogriseus 45-CD (12 U/mg) and S. olivochromogenes (17 U/mg) [19], and Thermotoga maritime AxeA (0.7 U/mg) [20].

\section{Discussion}

The quest for new microbial lipases and more costeffective ways to produce them has received increasing attention because of their potential use as industrial biocatalysts in diverse sectors. With the explosion of genomics, the number of sequenced genes encoding enzymes has increased 14 fold in eight years. However, when compared with the number of enzymes that have been biochemically characterized during the same period, this number has increased only around 3\% [21]. Through analysing the genome of the recently sequenced alkaliphilic fungus Acremonium alcalophilum, we identified a putative lipase, lipA. Lipases belong to a group of enzymes defined as carboxylesterases. This 
Table 1 Substrate specificity of the purified LipA on various substrates

\begin{tabular}{|c|c|}
\hline Substrate & Specific activity $^{\text {a }}(\mathrm{U} / \mathrm{mg})$ \\
\hline Xylose tetra-acetate & $58.84 \pm 2.32$ \\
\hline Oat spelt xylan & $14.12 \pm 4.34$ \\
\hline$p N P$ acetate $\left(C_{2}\right)$ & $0.14 \pm 0.03$ \\
\hline pNP butyrate $\left(C_{4}\right)$ & $2.80 \pm 0.04$ \\
\hline$p$ NP caprylate $\left(C_{8}\right)$ & $6.52 \pm 0.13$ \\
\hline$p$ NP myristate $\left(C_{14}\right)$ & $2.56 \pm 0.17$ \\
\hline pNP palmitate $\left(C_{16}\right)$ & $1.29 \pm 0.02$ \\
\hline pNP arabino-pyranoside & $N D^{b}$ \\
\hline pNP arabino-furanoside & ND \\
\hline pNP xylopyranoside & ND \\
\hline Methyl ferulate & ND \\
\hline Methyl cafeate & ND \\
\hline Methyl sinapinate & ND \\
\hline Methyl $p$-coumarate & ND \\
\hline
\end{tabular}

${ }^{a}$ Unit definition: 1 unit of activity is the amount necessary to hydrolyze $1.0 \mu \mathrm{mol}$ of substrate per minute at $40^{\circ} \mathrm{C}$ and $\mathrm{pH} 7.0$. Values are the mean \pm the standard deviation (SD) of three independent experiments. ${ }^{\mathrm{b}} \mathrm{ND}=$ not detectable. Deacetylation of xylose tetra-acetate and oat spelt xylan was evaluated by determining the amount of acetyl group released per milligram of protein and the hydrolysis of $p N P$ substrates was expressed relative to the amount of $p$-nitrophenol liberated pre milligram of LipA.

group of enzymes is well known for its activity towards substrates with a range of different sizes of carbon chains and although non-specific esterases are more active on short acyl chain esters, lipases have the capability to catalyze the hydrolysis of carboxylic ester bonds of water-insoluble long chains including natural fat [4].

To characterize $\operatorname{lip} A$, the heterologous production of LipA was tested in $A$. niger and transient expression in $N$. benthamiana. Attempts to produce LipA in $A$. niger were unsuccessful. While $A$. niger is known to be one of the most potent producers of extracellular enzymes, its ability to produce heterologous proteins is limited. The high level of proteases in the extracellular fluids can negatively impact the production of heterologous proteins [22]. Also, A. niger is a producer of organic acids at the industrial scale and prefers to grow in an acidic environment. Almost all extracellular enzymes of $A$. niger are active in acidic $\mathrm{pH}$ [23]. It is possible $A$. niger does not provide a suitable environment to produce enzymes that are active in neutral and alkaline $\mathrm{pH}$, owing to differences in protein folding and/or sensitivity to proteases. Nicotiana benthamiana, on the other hand, accumulated high levels of LipA, possibly because the enzyme was retained in the ER where conditions are conducive for proper folding, and the $\mathrm{pH}$ is in the neutral range [24], enabling accumulation, purification and characterization of the enzyme. These characteristics of plants for the production of heterologous enzymes from organisms that thrive in neutral or high $\mathrm{pH}$ might prove extremely useful in future production efforts.

The use of plants as bioreactors has gained increasing interest in the past few years as they offer several advantages over other heterologous systems, including low cost biomass production, considerable scale up potential and the ability to undertake complex post-translational modifications that are essential for the stabilization and/ or functionality of some proteins [25]. Our results confirm the usefulness of plants as bioreactors for the production of eukaryotic proteins. Moreover, even though the simplicity of culturing and genetic engineering of Escherichia coli makes it a preferable choice as an expression system for screening of candidate proteins, the lack of posttranslational modification mechanisms in this host such as glycosylation, protein maturation and limited formation of disulfide bonds, makes it an unsuitable system for large scale glycoprotein production. With that in mind, plant expression systems can play an important role in heterologous expression of proteins that are difficult to express in microbial hosts.

Lipases also have a variety of other biotechnological applications in diverse industrial sectors including the textile, food, pulp and paper, fat and oleochemical, pharmaceutical and in particular, the detergent industry where an estimated 1000 tons of lipases are added to approximately 13 billion tons of detergents each year [5]. The optimal activity at $\mathrm{pH} 8.0$ and broad thermostability $\left(20\right.$ to $50^{\circ} \mathrm{C}$ ) of LipA are characteristics highly desirable to the detergent industry, where enzymes are used as additives to detergents at low temperatures and high $\mathrm{pH}$ [26].

Functional analysis of a hypothetical, in silico annotated, protein often will start with known substrates for

Table 2 Kinetics parameters and/or specific activities of LipA on pNP substrates

\begin{tabular}{lccc}
\hline & $\mathbf{K m}(\mathbf{m M})$ & $\mathbf{V}_{\max }(\boldsymbol{\mu m o l} / \mathbf{m i n} / \mathbf{m g})$ & Specific Activity at $\mathbf{0 . 2} \mathbf{~ m M}(\boldsymbol{\mu m o l} / \mathbf{m i n} / \mathbf{m g})$ \\
\hline $\boldsymbol{p N P}$ acetate $\left(\boldsymbol{C}_{\mathbf{2}}\right)$ & $0.15 \pm 0.00^{*}$ & $0.24 \pm 0.06$ & $0.14 \pm 0.03$ \\
$\boldsymbol{p N P}$ butyrate $\left(\boldsymbol{C}_{\mathbf{4}}\right)$ & $0.16 \pm 0.00$ & $4.73 \pm 0.07$ & $2.80 \pm 0.04$ \\
$\boldsymbol{p N P}$ caprylate $\left(\boldsymbol{C}_{\mathbf{8}}\right)$ & $0.10 \pm 0.00$ & $9.45 \pm 0.20$ & $6.52 \pm 0.13$ \\
$\boldsymbol{p N P}$ myristate $\left(\boldsymbol{C}_{\mathbf{1 4}}\right)$ & $0.07 \pm 0.00$ & $3.42 \pm 0.24$ & $2.56 \pm 0.17$ \\
$\boldsymbol{p N P}$ palmitate $\left(\boldsymbol{C}_{\mathbf{1 6}}\right)$ & $0.10 \pm 0.00$ & $1.84 \pm 0.04$ & $1.29 \pm 0.02$ \\
\hline
\end{tabular}

*Values are means \pm SD $(n=3)$. 
biochemical enzymatic characterization. Generally, the biochemical characterization of lipases in the literature is analyzed using $p \mathrm{NP}$ esters as the substrate [10]. However, lipases are well known for their broad specific activity, and in some cases are active on more than 50 different ester linked substrates [27], including hydroxycinnamoyl and carbohydrate esters. Biochemical characterization of LipA showed a broad specificity towards $p$ NP esters of various carbon chain lengths including the long-chain $p \mathrm{NP}$ palmitate, a typical lipase substrate but also towards acetylated substrates. Since carboxyl and carbohydrate esterases are from the same $\alpha / \beta$ hydrolase superfamily and most often share the same catalytic domain, the structural analysis and site-directed mutagenesis of LipA should be performed in the future to evaluate the importance of enzyme structure, binding site and catalytic triad on both esterase activities.

The hemicellulose and pectin structures of plant cell walls are decorated with a variety of side chains that are attached to their backbone, including acetyl groups. These acetyl groups specifically can represent up to $4.32 \%$ of dry weight in a variety of crop species [28]. Deacetylation of aspen wood and wheat straw, with up to $90 \%$ acetyl ester removal, has indicated that as the xylan becomes increasingly deacetylated, it becomes 5-7 times more digestible [29]. Thus, the discovery and characterization of enzymes that can facilitate the decomposition of these polysaccharides could improve the viability of the cellulosic ethanol industry. Since the plant-produced LipA showed activity against both acetylated xylan and xylose tetra-acetate, the results obtained in this study indicate that LipA has the potential to be used as a supplement to enzymatic cocktails for the hydrolysis of lignocellulosic biomass.

Synergism between xylanases and acetyl xylan esterases has been reported to dramatically improve the release of sugars from xylan and glucan [30-32]. Since the acetylxylan esterase activity of LipA was confirmed on oat spelt xylan and xylose tetra-acetate, it is reasonable to suggest that LipA could be used in combination with other xylanases for future development of biological pretreatment for the cellulosic bioproducts industry and should be further investigated. Additionally, considering that the use of plants to produce industrial proteins is projected to have a cost 10-fold lower than microbial based production system, assuming that the foreign protein accumulates to $10 \%$ of TSP [33] and that with costsensitive applications, such as biofuels, the possibility of cost reduction to produce a key component for plant cell wall deconstruction may be crucial to make biofuels economically viable, these results represent an important step in making this enzyme commercially available for industrial purposes such as the cellulosic ethanol production.

\section{Conclusions}

The results described here show that the Acremonium alcalophilum lipase LipA is a glycoprotein that was efficiently expressed in $N$. benthamiana. The enzyme is very versatile exhibiting both acetylxylan esterase and lipase activities. Moreover, the LipA purified and characterized here has properties potentially useful for diverse industry sectors and its applications should be further developed.

\section{Methods}

\section{Amplification of the lipA gene}

The protein sequence of the Acremonium alcalophilum genome v2.0, http://genome.jgi-psf.org/Acral2/Acral2. home.html, was analyzed for extracellular biomassdegrading enzymes. SignalP v3.0, http://www.cbs.dtu.dk, was used to detect the presence of secretory signal peptide and additional protein domains were examined using the integrated protein signature databases and tools at the European Bioinformatics Institute, http:// www.ebi.ac.uk/Tools/pfa/iprscan/. The A. alcalophilum protein with the ID 1062717 was found to possess both a secretory signal peptide and a lipase domain, and we called it LipA (for the first identified lipase from this organism) and its encoding gene as lipA. Complementary DNA was synthesized [34] using RNA prepared from $A$. alcalophilum strain JCM 7366 cultured in a mixture of alfalfa and barley straw. Gene-specific primers with the Gateway $^{\circ}$ recombination sequences were used to PCRamplify the lipA gene using synthesized cDNA as template. The forward and reverse primers used were, respectively, 5' -GGGGACAAGTTTGTACAAAAAAGC AGGCTATGTTGGGCTTCGCCTCGCT-3' and 5' -GG GGACCACTTTGTACAAGAAAGCTGGGTTCAGCC TTCAGCCGATATTG-3'.

\section{Plant expression vectors}

The amplified lipA gene was cloned into the Gateway ${ }^{\circ}$ donor vector $\mathrm{pDONR} / \mathrm{Zeo}^{\mathrm{Tm}}$ (Invitrogen, Carlsbad, USA) and the integrity of the construct was validated by sequence analysis. Using the Gateway cloning system, the lipA gene was subsequently subcloned into the pCaMGate-ER plant binary expression vector (Conley et al., in preparation), a variation of pCaMterX [35], a binary vector that places the gene of interest under control of the double-enhanced cauliflower mosaic virus $35 \mathrm{~S}$ promoter [36] and the nopaline synthase (nos) terminator [37]. The pCamGate-ER vector harbors the tCUP translation enhancer [38], the Pr1b secretory signal peptide from Nicotiana benthamiana [39] and $\mathrm{Xpress}^{\mathrm{Tm}}$ tag, attR1, followed by the $c c d \mathrm{~B}$ gene, attR2, C-Myc detection/purification tag, and a KDEL ERretrieval signal (Figure 2). 


\section{Protein production in $N$. benthamiana leaves and total soluble protein extraction}

A suspension of Agrobacterium tumefaciens strain EHA105 carrying the expression construct was mixed with an equal amount of Agrobacterium culture containing the suppressor of post-transcriptional gene silencing p19 from cymbidium ringspot virus (CymRSV) [12]. The suspension was co-infiltrated into leaves of 5-6 week old $N$. benthamiana plants through the stomata of abaxial leaf epidermis using a syringe [40]. Infiltrated plants were maintained in a controlled growth chamber for 4 days at $22^{\circ} \mathrm{C}$, with a $16 \mathrm{~h}$ photoperiod. Five leaf disks $(7 \mathrm{~mm})$ from infiltrated tissue were collected and ground in liquid nitrogen using $2.3 \mathrm{~mm}$ ceramic beads (BioSpec Products, 11079125z, Bartlesville, USA) in a TissueLyser (Qiagen ${ }^{\circledR}$ ). Total soluble protein was extracted from the ground tissue in ice-cold phosphatesaline buffer (PBS), pH 7.4 supplemented with $0.1 \%$ Tween-20, 2\% PVPP (polyvinyl polypyrrolidone), $1 \mathrm{mM}$ EDTA (ethylenediaminetetraacetic acid), $100 \mathrm{mM}$ sodium acorbate, $1 \mathrm{mM}$ PMSF (phenylmethylsulfonyl fluoride) and $1 \mu \mathrm{g} / \mathrm{ml}$ leupeptin. Protein extraction from a control plant infiltrated only with p19 as a negative control was also performed under similar conditions. Total soluble protein (TSP) concentration was determined using the Bradford assay [41] with bovine serum albumin as standard.

\section{Determination of molecular mass and quantification of LipA protein production levels}

The molecular mass of the enzyme was determined by gel electrophoresis. Plant protein extract was separated by sodium dodecylsulphate-polyacrylamide gel electrophoresis (SDS-PAGE) (10\%) and transferred to PVDF membrane. To detect the recombinant protein the membrane was incubated with primary mouse anti-C-myc monoclonal antibody (Genscript, A00864, Piscataway, USA). The primary antibody was detected with HRP-conjugated goat antimouse IgG antibody (Bio-Rad, 170-6516, Hercules, USA) and visualized using the ECL detection kit (GE healthcare, Mississauga, Canada) and autoradiography as described by the manufacturer.

Western blots were analyzed using image densitometry with TotalLab TL100 software (Nonlinear Dynamics, Durhan, USA). Intensities were determined by comparison with known amounts of a synthetic positive control protein containing a cellulose-binding domain and a Cmyc tag (synthesized by Genscript, Piscataway, USA).

Samples were also analyzed by staining SDS-PAGE gels with Gel-Code Blue reagent (PIERCE, 24590). The amount of protein was determined by comparing to known amounts of BSA loaded on the same gel, using image densitometry with TotalLab TL100 software (Nonlinear Dynamics, Durhan, USA).

\section{Protein purification}

Total soluble protein was extracted from plants producing LipA four days post infiltration (dpi) as described above and purified by affinity chromatography using a cMyc tagged Protein MILD PURIFICATION KIT (MBL, 3305, Woburn, USA) according to the manufacturer's instructions.

\section{Deglycosylation analysis}

Enzymatic deglycosylation of transiently produced LipA was carried out on purified protein using PNGase $\mathrm{F}$ (Sigma-Aldrich, G5166, St. Louis, USA) according to the manufacturer's instructions. PNGaseF cleaves all highmannose, hybrid, and complex-type oligosaccharides from $N$-linked glycoproteins, except for those glycans containing a core $\alpha(1,3)$-linked fucose residue. The digestion was carried out at $37^{\circ} \mathrm{C}$ for $3 \mathrm{~h}$ followed by SDSPAGE analysis under reducing conditions and westernblot analysis with anti-C-myc antibody. Control samples were treated the same, except that no PNGase F was added.

\section{Enzyme assays}

LipA activity was determined by measuring $p$ nitrophenol $(p \mathrm{NP})$ release from $p$-nitrophenyl caprylate $[42,43]$. The reaction was carried out in 96 well flat bottom microplates using $1 \mathrm{mM} p$-nitrophenol ester substrate in $100 \mathrm{mM}$ phosphate buffer $\mathrm{pH} 8.0$ incubated at $40^{\circ} \mathrm{C}$ for $30 \mathrm{~min}$. Purified enzyme was added to the reaction and samples were kept in the dark to avoid autohydrolysis of the substrate. $p$-nitrophenol in $100 \mathrm{mM}$ phosphate buffer was used as the standard and the color intensity was measured at $405 \mathrm{~nm}$ in a Synergy HT microtitre plate reader (Biotek, Winooski, VT, USA). One unit of lipase activity was defined as the amount of enzyme releasing $1.0 \mu \mathrm{mol}$ of $p$-nitrophenol per minute under assay conditions. The optimum enzyme $\mathrm{pH}$ was measured using sodium-acetate (100 mM, pH 4.0-5.0), sodium-phosphate (100 mM, pH 6.0-9.0) and sodium carbonate (100 mM, pH 10.0-11.0) buffers incubated at $40^{\circ} \mathrm{C}$ for $30 \mathrm{~min}$. The optimum temperature was determined in the range of $20^{\circ} \mathrm{C}$ to $90^{\circ} \mathrm{C}$ in $100 \mathrm{mM}$ sodiumphosphate buffer pH 7.0 incubated for $30 \mathrm{~min}$.

\section{Substrate specificity and kinetics analysis}

Substrate specificity was measured by incubating the purified lipase with $p \mathrm{NP}$-derived esters of various lengths ( $p \mathrm{NP}$ acetate, $\mathrm{C} 2 ; p \mathrm{NP}$ butyrate, $\mathrm{C} 4 ; p \mathrm{NP}$ caprylate, $\mathrm{C} 8 ; p \mathrm{NP}$ myristate, $\mathrm{C} 14 ; p \mathrm{NP}$ palmitate, C16) and measuring the amount of $p \mathrm{NP}$ released. One unit of esterase/lipase activity was defined as the amount of enzyme required to release $1 \mu \mathrm{mol} / \mathrm{min}$ at $40^{\circ} \mathrm{C}$. To define the enzyme kinetics, specific activity and kinetic constants were measured using the $p$ NP derived ester over 
eight different substrate concentrations (between $10 \mu \mathrm{M}$ and $1 \mathrm{mM})$ to determine the initial reaction rate of the enzyme.

Hydroxycinnamate esters (methyl ferulate, methyl caffeate, methyl $p$-coumarate and methyl sinapinate) were also evaluated as substrates by measuring the release of the corresponding phenolic acids (ferulic acid, caffeic acid, $p$-coumaric acid and sinapinic acid). The $150 \mu \mathrm{l}$ reaction of $0.2 \mathrm{mM}$ substrate in $100 \mathrm{mM}$ sodium phosphate buffer, pH 7.0 was used to measure the absorbance variation at $335 \mathrm{~nm}$ in the Synergy HT plate reader (BioTek ${ }^{\oplus}$, Winooski, VT, USA). The result of LipA reaction against hydroxycinnamate esters substrate was compared against reactions of feruloyl esterase from Anaeromyces mucronatus as positive control under the same conditions.

The liberation of acetic acid from xylose tetra-acetate and oat spelt xylan (Sigma Aldrich, product no. X-0627) was used to quantify acetylxylan esterase activity using the R-Biopharm enzymatic analysis kit (Darmstadt, Germany, Cat no. 10148261035) according to manufacturer's instructions. The assays were performed in sodium phosphate buffer (50 mM, pH 8.0).

\begin{abstract}
Abbreviations
LipA: Gene encoding LipA protein from A. alcalophilum; Axe: Acetylxylan esterase; TSP: Total soluble protein; SDS-PAGE: Sodium dodecylsulphatepolyacrylamide gel electrophoresis; PNGase: F Peptide -N-Glycosidase F; Bp: Base pair; pNP: -nitrophenol; PCR: Polymerase chain reaction; ER: Endoplasmic reticulum; PVPP: Polyvinyl polypyrrolidone; PBS: Phosphatebuffered saline; EDTA: Ethylenediaminetetraacetic acid;

PMSF: Phenylmethylsulfonyl fluoride; HRP: Horse radish peroxidase; IgG: Immunoglobulin G; tCUP: Tobacco cryptic upstream promoter: Pr1b: Pathogenesis-related protein 1b of tobacco; $c c d B$ : Gene encoding the cytotoxic protein $\mathrm{CcdB}$.
\end{abstract}

\section{Competing interests}

The authors declare that they have no competing interests.

\section{Authors' contributions}

EOP designed the constructs, produced the enzyme, analyzed enzyme activity and drafted the manuscript. TM provided materials, lab space and technical help for activity assays, AT provided the CDNA, and the results in A. niger, RM conceived of the study and participated in its design. EOP, TM, AT and RM edited the manuscript. All authors read and approved the final manuscript.

\section{Acknowledgements}

We thank Angelo Kaldis and Krysty Munns for technical support. We are grateful to Alex Molnar for help with preparing the figures. This study was supported by the Agriculture and Agri-Food Canada's A-base funding Program and the Agricultural Bioproducts Innovation Program through the Cellulosic Biofuels Network. The authors declare no conflict of interest.

\section{Author details}

${ }^{1}$ Agriculture and Agri-Food Canada, 1391 Sandford Street, London, ON N5V 4T3, Canada. 'Department of Biology, The University of Western Ontario, London, ON N6A 5B7, Canada. ${ }^{3}$ Centre for Structural and Functional Genomics, Concordia University, Montreal, Quebec H4B 1R6, Canada. ${ }^{4}$ Agriculture and Agri-Food Canada, Lethbridge Research Centre, Lethbridge, AB T1J 4B1, Canada.

Received: 17 May 2013 Accepted: 31 July 2013

Published: 1 August 2013

\section{References}

1. Okada G, Niimura Y, Sakata T, Uchimura T, Ohara N, Suzuki H, Kozaki M: Acremonium alcalophilum, a new alkalophilic cellulolytic hyphomycete. Trans Mycol Soc Jpn 1993, 34:171-185.

2. Castro-Ochoa LD, Rodríguez-Gómez C, Valerio-Alfaro G, Oliart Ros R: Screening, purification and characterization of the thermoalkalophilic lipase produced by Bacillus thermoleovorans CCR11. Enzyme Micob Technol 2005, 37:648-654.

3. Shangguan JJ, Liu YQ, Wang FJ, Zhao J, Fan LQ, Li SX, Xu JH: Expression and characterization of a novel lipase from Aspergillus fumigatus with high specific activity. Appl Biochem Biotechnol 2011, 165:949-962.

4. Chahiniana H, Sarda L: Distinction between esterases and lipases: comparative biochemical properties of sequence-related carboxylesterases. Protein Pept Lett 2009, 16:1149-1161.

5. Jaeger K-E, Reetz MT: Microbial lipases form versatile tools for biotechnology. Trends Biotechnol 1998, 16:396-403.

6. Singh A, Mukhopadhyay M: Overview of fungal lipase: a review. Appl Biochem Biotechnol 2012, 166:486-520.

7. Jeoh T, Michener W, Himmel M, Decker S, Adney W: Implications of cellobiohydrolase glycosylation for use in biomass conversion. Biotechnol Biofuels 2008, 1:1-12

8. Ahmad A, Pereira EO, Conley AJ, Richman AS, Menassa R: Green biofactories: recombinant protein production in plants. Recent Pat Biotechnol 2010, 4:242-259.

9. Zhu S-S: Cloning and characterization of two lipases and a lysophospholipase from Aspergillus niger Masters. Biology: Concordia University; 2007.

10. Jaeger KE, Dijkstra BW, Reetz MT: Bacterial biocatalysts: molecular biology, three-dimensional structures, and biotechnological applications of lipases. Annu Rev Microbiol 1999, 53:315-351.

11. Wohlfarth S, Hoesche C, Strunk C, Winkler UK: Molecular genetics of the extracellular lipase of Pseudomonas aeruginosa PAO1. J Gen Microbiol 1992, 138:1325-1335.

12. Silhavy D, Molnar A, Lucioli A, Szittya G, Hornyik C, Tavazza M, Burgyan J: A viral protein suppresses RNA silencing and binds silencing-generated, 21- to 25-nucleotide double-stranded RNAs. EMBO J 2002, 21:3070-3080.

13. Yuasa K, Maeshima M: Purification, properties, and molecular cloning of a novel $\mathrm{Ca}(2+)$-binding protein in radish vacuoles. Plant Physiol 2000, 124:1069-1078.

14. Karen AM: In Planta Production of Cell Wall Degrading Enzymes. In Handbook of Bioenergy Crop Plants. Edited by Kole C, Joshi CP, Shonnard DR. Boca Raton, FL: CRC Press; 2012:55-73.

15. Kim HK, Park SY, Lee JK, Oh TK: Gene cloning and characterization of thermostable lipase from Bacillus stearothermophilus L1. Biosci Biotechnol Biochem 1998, 62:66-71.

16. Lee HK, Ahn MJ, Kwak SH, Song WH, Jeong BC: Purification and characterization of cold active lipase from psychrotrophic Aeromonas sp: LPB 4. J Microbiol 2003, 41:22-27.

17. Degrassi G, Okeke BC, Bruschi CV, Venturi V: Purification and characterization of an acetyl xylan esterase from Bacillus pumilus. Appl Environ Microbiol 1998, 64:789-792.

18. Kam DK, Jun H-S, Ha JK, Inglis GD, Forsberg CW: Characteristics of adjacent family 6 acetylxylan esterases from Fibrobacter succinogenes and the interaction with the Xyn10E xylanase in hydrolysis of acetylated xylan. Can J Microbiol 2005, 51:821-832.

19. Johnson KG, Fontana JD, MacKenzie CR: Measurement of acetylxylan esterase in Streptomyces. Methods Enzymol 1988, 160:551-560.

20. Tsuchiya A, Nakazawa H, Toida J, Ohnishi K, Sekiguchi J: Cloning and nucleotide sequence of the mono- and diacylglycerol lipase gene (mdlB) of Aspergillus oryzae. FEMS Microbiol Lett 1996, 143:63-67.

21. Cantarel BL, Coutinho PM, Rancurel C, Bernard T, Lombard V, Henrissat B: The carbohydrate-active enzymes database (CAZy): an expert resource for Glycogenomics. Nucleic Acids Res 2009, 37:233-238.

22. van den Hombergh JPTW, van de Vondervoort PJI, Fraissinet-Tachet L, Visser $\mathrm{J}$ : Aspergillus as a host for heterologous protein production: the problem of proteases. Trends Biotechnol 1997, 15:256-263.

23. Murphy C, Powlowski J, Wu M, Butler G, Tsang A: Curation of characterized glycoside hydrolases of fungal origin. Database (Oxford) 2011, 2011:bar020.

24. Vitale A, Denecke J: The endoplasmic reticulum-gateway of the secretory pathway. Plant Cell 1999, 11:615-628.

25. Menassa R, Ahmad A, Joensuu JJ: Transient expression using agroinfiltration and its applications in molecular farming. In Molecular 
farming in plants: recent advances and future prospects. Edited by Wang A, Ma S. Dordrecht, Heidelberg, London, New York: Springer Netherlands; 2012:183-198.

26. Margesin R, Schinner F: Properties of cold-adapted microorganisms and their potential role in biotechnology. J Biotechnol 1994, 33:1-14.

27. Martinez-Martinez M, Alcaide M, Tchigvintsev A, Reva O, Polaina J, Bargiela R, Guazzaroni ME, Chicote A, Canet A, Valero F, et al: Biochemical diversity of carboxyl esterases and lipases from lake arreo (Spain): a metagenomic approach. Appl Environ Microbiol 2013, 79:3553-3562.

28. Pronyk C, Mazza G: Fractionation of triticale, wheat, barley, oats, canola, and mustard straws for the production of carbohydrates and lignins. Bioresour Technol 2012, 106:117-124.

29. Grohmann K, Mitchell DJ, Himmel ME, Dale BE, Schroeder HA: The role of ester groups in resistance of plant cell wall polysaccharides to enzymatic hydrolysis. Appl Biochem Biotechnol 1989, 20-21:45-61.

30. Zhang J, Siika-Aho M, Tenkanen M, Viikari L: The role of acetyl xylan esterase in the solubilization of xylan and enzymatic hydrolysis of wheat straw and giant reed. Biotechnol Biofuels 2011, 4:1-10.

31. Huang YC, Chen GH, Chen YF, Chen WL, Yang CH: Heterologous expression of thermostable acetylxylan esterase gene from Thermobifida fusca and its synergistic action with xylanase for the production of xylooligosaccharides. Biochem Biophys Res Commun 2010, 400:718-723.

32. Selig MJ, Knoshaug EP, Adney WS, Himmel ME, Decker SR: Synergistic enhancement of cellobiohydrolase performance on pretreated corn stover by addition of xylanase and esterase activities. Bioresour Technol 2008, 99:4997-5005.

33. Hood E, Woodard S: Industrial proteins produced from transgenic plants In Plants as factories for protein production. Edited by Hood E, Howard J. Dordrecht: Springer Netherlands; 2002:119-135.

34. Semova N, Storms R, John T, Gaudet P, Ulycznyj P, Min XJ, Sun J, Butler G, Tsang A: Generation, annotation, and analysis of an extensive Aspergillus niger EST collection. BMC Microbiol 2006, 6:1-10.

35. Harris $L$, Gleddie SC: A modified Rp/3 gene from rice confers tolerance of the Fusarium graminearum mycotoxin deoxynivalenol to transgenic tobacco. Physiol Mol Plant Pathol 2001, 58:173-181.

36. Kay R, Chan A, Daly M, McPherson J: Duplication of CaMV 355 promoter sequences creates a strong enhancer for plant genes. Science 1987, 236:1299-1302.

37. Bevan M, Barnes WM, Chilton MD: Structure and transcription of the nopaline synthase gene region of T-DNA. Nucleic Acids Res 1983, 11:369-385

38. Wu K, Malik K, Tian L, Hu M, Martin T, Foster E, Brown D, Miki B: Enhancers and core promoter elements are essential for the activity of a cryptic gene activation sequence from tobacco, tCUP. Mol Genet Genomics 2001 265:763-770.

39. Cutt JR, Dixon DC, Carr JP, Klessig DF: Isolation and nucleotide sequence of cDNA clones for the pathogenesis-related proteins PR1a, PR1b and PR1c of Nicotiana tabacum cv: Xanthi nc induced by TMV infection. Nucleic Acids Res 1988, 16:9861.

40. Conley AJ, Joensuu JJ, Jevnikar AM, Menassa R, Brandle JE: Optimization of elastin-like polypeptide fusions for expression and purification of recombinant proteins in plants. Biotechnol Bioeng 2009, 103:562-573,

41. Bradford MM: A rapid and sensitive method for the quantitation of microgram quantities of protein utilizing the principle of protein-dye binding. Anal Biochem 1976, 72:248-254.

42. Qi M, Wang P, Selinger LB, Yanke LJ, Forster RJ, McAllister TA: Isolation and characterization of a ferulic acid esterase (Fae1A) from the rumen fungus Anaeromyces mucronatus. J Appl Microbiol 2011, 110:1341-1350.

43. Ghatora SK, Chadha BS, Saini HS, Bhat MK, Faulds CB: Diversity of plant cell wall esterases in thermophilic and thermotolerant fungi. J Biotechnol 2006, 125:434-445.

\section{doi:10.1186/1754-6834-6-111}

Cite this article as: Pereira et al:: The production and characterization of a new active lipase from Acremonium alcalophilum using a plant bioreactor. Biotechnology for Biofuels 2013 6:111.

\section{Submit your next manuscript to BioMed Central and take full advantage of:}

- Convenient online submission

- Thorough peer review

- No space constraints or color figure charges

- Immediate publication on acceptance

- Inclusion in PubMed, CAS, Scopus and Google Scholar

- Research which is freely available for redistribution 